\title{
Length-weight relations of 12 freshwater fish species (Actinopterygii: Cypriniformes) including two endangered species, Cobitis choii (Cobitidae) and Gobiobotia naktongensis (Cyprinidae), in the Geum River, South Korea
}

\author{
Seung-Ho BAEK ${ }^{1,2}$, Sang-Hyeon PARK ${ }^{1}$, Jeong-Hui KIM ${ }^{1}$, Jo-Hee YOON ${ }^{3}$, Jeong-Suk MOON \\ Dong-Hwan $\mathrm{KIM}^{5}$, Ju-Duk YOON ${ }^{6}$ \\ 1 EcoResearch incorporated, Gongju, Republic of Korea \\ 2 Department of Environmental Engineering, Chungbuk National University, Cheongju, Republic of Korea \\ 3 Geum River Environment Research Center, National Institute of Environment Research, Okcheon, Republic of Korea \\ 4 National Institute of Environmental Research, Incheon, Republic of Korea \\ 5 Environment Impact Assessment Team, National Institute of Ecology, Seocheon, Republic of Korea \\ 6 Research Center for Endangered species, National Institute of Ecology, Yeongyang, Republic of Korea
}

http://zoobank.org/1BF99B29-AF1D-4223-8C7A-9C12636E1737

Corresponding author: Ju-Duk Yoon (zmszmsqkek@hanmail.net)

Academic editor: Rodolfo Reyes • Received 8 December 2021 • Accepted 26 January 2022 • Published 10 February 2022

Citation: Baek S-H, Park S-H, Kim J-H, Yoon J-H, Moon J-S, Kim D-H, Yoon J-D (2022) Length-weight relations of 12 freshwater fish species (Actinopterygii: Cypriniformes) including two endangered species, Cobitis choii (Cobitidae) and Gobiobotia naktongensis (Cyprinidae), in the Geum River, South Korea. Acta Ichthyologica et Piscatoria 52(1): 9-12. https://doi.org/10.3897/aiep.52.79067

\begin{abstract}
Length-weight relations (LWRs) of 12 freshwater fish species from the Geum River, South Korea were estimated. The following species representing the family Cobitidae, Xenocyprididae, Acheilognathidae, and Gobionidae were studied: Cobitis choii Kim et Son, 1984; Opsariichthys uncirostris (Temminck et Schlegel, 1846); Zacco platypus (Temminck et Schlegel, 1846); Tanakia lanceolata (Temminck et Schlegel, 1846); Acheilognathus rhombeus (Temminck et Schlegel, 1846); Hemibarbus labeo (Pallas, 1776); Gobiobotia naktongensis Mori, 1935; Hemibarbus longirostris (Regan, 1908); Microphysogobio jeoni Kim et Yang, 1999; Pseudogobio esocinus (Temminck et Schlegel, 1846); Pseudorasbora parva (Temminck et Schlegel, 1846); Squalidus japonicus (Sauvage, 1883). Parameter $b$ ranged from 2.820 (P. parva) to 3.485 (C. choii), and parameter $a$ ranged from 0.0015 (C. choii) to 0.0145 (A. rhombeus). The LWR for $C$. choii and G. naktongensis, endangered species in South Korea, was estimated for the first time. Our results could be useful as baseline information for evaluating population status.
\end{abstract}

\section{Keywords}

endangered species, fish stock management, Korean endemic species, LWRs, weight-length relations, WLRs

\section{Introduction}

The length-weight relations (LWRs) are derived from regression analysis using a paired dataset of length and weight of specific species that can be used to estimate the weight corresponding to a given length (Le Cren 1951), and parameters $a$ and $b$ of the LWRs are determined by the body shape and growth patterns of the species (Froese 2006). The LWR provides baseline information for stock management as indicators of stock status, including growth, sexual maturity, and food availability (Le Cren 1951; Al-Zibdah and Odat 2007; Karna et al. 2012). In 
addition, because the body shape and growth patterns of fish are related to their habitat status, including food availability and predation pressure (Brönmark and Miner 1992), LWRs are useful not only for fisheries research but also for ecological studies.

LWR estimations from various populations are required to estimate the relative weight index, which is a useful tool for comparing fish conditions across populations or species, unlike the condition factor and relative condition factor, which can only be used to compare conditions within a population (Froese 2006). FishBase currently provides LWR estimations for 6098 fish species, but LWR data are lacking for some species (Froese and Pauly 2021).

Cobitis choii Kim et Son, 1984 and Gobiobotia naktongensis Mori, 1935 are endemic Korean species with restricted distribution because they only inhabit streams with wide and clear sand streambeds with moderate water flow (Ko et al. 2012; Kim et al. 2014). Cobitis choii and $G$. naktongensis have both been identified as Class I endangered species by the Korean Ministry of Environment (NIBR 2018) because of their restricted distribution and small population size.

In the presently reported study, we provide LWR data for 12 freshwater fish species, including $C$. choii and $G$. naktongensis, which have not been previously reported.

\section{Material and methods}

The following species representing the families Cobitidae, Xenocyprididae, Acheilognathidae, and Gobionidae were studied: Cobitis choii; Opsariichthys uncirostris (Temminck et Schlegel, 1846); Zacco platypus (Temminck et Schlegel, 1846); Tanakia lanceolata (Temminck et Schlegel, 1846); Acheilognathus rhombeus (Temminck et Schlegel, 1846); Hemibarbus labeo (Pallas, 1776); Gobiobotia naktongensis; Hemibarbus longirostris (Regan, 1908); Microphysogobio jeoni Kim et Yang, 1999;
Pseudogobio esocinus (Temminck et Schlegel, 1846); Pseudorasbora parva (Temminck et Schlegel, 1846); Squalidus japonicus (Sauvage, 1883).

The fishes were collected from the Geum River $\left(36^{\circ} 27^{\prime} 14.89^{\prime \prime} \mathrm{N}, 127^{\circ} 5^{\prime} 37.70^{\prime \prime} \mathrm{E}\right)$ using a cast net (mesh $7 \mathrm{~mm}$ ) and a kick net (mesh $4 \mathrm{~mm}$ ) from March to October 2021. The total length $(L)[\mathrm{cm}]$ and weight $(W$, wet weight) $[\mathrm{g}]$ were measured immediately at the capture site. The fishes were examined after being anesthetized using $0.1 \mathrm{~g} \cdot \mathrm{L}^{-1}$ ethyl 3-aminobenzoate methanesulfonate salt (Sigma-Aldrich, Munich, Germany). The total length was measured using a digital caliper to the nearest $0.1 \mathrm{~cm}$. The weight of $G$. naktongensis and $C$. choii was determined using a digital balance to the nearest $0.01 \mathrm{~g}$, while other fishes were weighed to the nearest $0.1 \mathrm{~g}$. After the examination and recovery, the fishes were released from the recovery tank $(100 \times$ $100 \times 80 \mathrm{~cm})$.

The LWR for each species was estimated using the regression equation

$$
W=a L^{b}
$$

where $a$ and $b$ are parameters of the equation (Le Cren 1951; Ricker 1973; Froese 2006). Before the regression analysis, outliers were removed by linear regression of the log-transformed equation (Froese 2006). Scientific names for all species and family assignments were based on Eschmeyer's Catalog of Fishes (Fricke et al. 2021).

\section{Results}

The LWRs of the 12 species were estimated, and the results are presented in Table 1. A total of 938 individuals were examined, and the sample size, ranges of total length, and weight of each species are presented. The total length ranges for 11 species were wide enough to include juveniles to adults, but Hemibarbus labeo only

Table 1. Summary of length-weight relations for 12 freshwater fish species in the Geum River, South Korea.

\begin{tabular}{|c|c|c|c|c|c|c|c|c|c|}
\hline \multirow[t]{2}{*}{ Species } & \multirow[t]{2}{*}{$N$} & \multirow{2}{*}{$\begin{array}{c}\text { Total length } \\
{[\mathrm{cm}]}\end{array}$} & \multirow[t]{2}{*}{ Weight [g] } & \multicolumn{6}{|c|}{ Regression parameters } \\
\hline & & & & $a$ & $95 \%$ CL of a & $\boldsymbol{B}$ & $95 \%$ CL of $b$ & $r^{2}$ & BE of $b$ \\
\hline Cobitis choii & 29 & $3.5-8.5$ & $0.13-2.66$ & 0.0015 & $0.0008-0.0029$ & 3.485 & $3.139-3.831$ & 0.938 & $3.05(2.87-3.23)$ \\
\hline Opsariichthys uncirostris & 126 & $5.9-23.5$ & $1.0-93.6$ & 0.0035 & $0.0029-0.0042$ & 3.231 & $3.154-3.309$ & 0.982 & $3.08(3.03-3.13)$ \\
\hline Zacco platypus & 91 & $4.8-14.8$ & $0.9-29.0$ & 0.0063 & $0.0052-0.0075$ & 3.105 & $3.019-3.190$ & 0.983 & $3.09(3.05-3.13)$ \\
\hline Tanakia lanceolata & 90 & $5.8-11.2$ & $1.9-16.6$ & 0.0070 & $0.0051-0.0096$ & 3.214 & $3.059-3.368$ & 0.950 & $3.05(2.92-3.18)$ \\
\hline Acheilognathus rhombeus & 31 & $6.9-9.6$ & $4.2-11.7$ & 0.0145 & $0.0107-0.0196$ & 2.961 & $2.815-3.108$ & 0.983 & $3.12(2.98-3.26)$ \\
\hline Hemibarbus labeo & 165 & $6.6-20.0$ & $2.1-53.6$ & 0.0061 & $0.0051-0.0072$ & 3.044 & $2.970-3.117$ & 0.976 & $3.10(3.05-3.15)$ \\
\hline Gobiobotia naktongensis & 94 & $2.4-6.0$ & $0.08-1.30$ & 0.0050 & $0.0044-0.0056$ & 3.054 & $2.967-3.142$ & 0.981 & $3.13(2.96-3.30)$ \\
\hline Hemibarbus longirostris & 37 & $7.5-14.8$ & $3.2-22.4$ & 0.0065 & $0.0047-0.0092$ & 3.021 & $2.873-3.169$ & 0.979 & $3.15(3.03-3.27)$ \\
\hline Microphysogobio jeoni & 45 & $4.7-9.5$ & $0.5-5.4$ & 0.0028 & $0.0019-0.0042$ & 3.344 & $3.133-3.556$ & 0.959 & $3.17(3.02-3.32)$ \\
\hline Pseudogobio esocinus & 114 & $3.3-17.8$ & $0.2-39.7$ & 0.0042 & $0.0036-0.0050$ & 3.153 & $3.078-3.228$ & 0.984 & $3.12(3.07-3.17)$ \\
\hline Pseudorasbora parva & 39 & $2.7-9.3$ & $0.2-6.3$ & 0.0113 & $0.0098-0.0130$ & 2.820 & $2.745-2.895$ & 0.993 & $3.12(3.07-3.17)$ \\
\hline Squalidus japonicus & 77 & $6.1-11.3$ & $1.9-14.9$ & 0.0064 & $0.0044-0.0093$ & 3.166 & $2.978-3.354$ & 0.937 & $3.16(3.03-3.29)$ \\
\hline
\end{tabular}

$N=$ number of specimens studied; BE of $b=$ Bayesian estimates of $b$ (Froese et al. 2014); Bold font indicates South Korean endangered species; Weight was measured to the nearest $0.01 \mathrm{~g}$; Text in shaded cells marks the species where only juveniles were included in the study. 
included juveniles. Parameters $a$ and $b$ are presented with $95 \%$ confidence limits. The coefficient of determination $\left(r^{2}\right)$ for all species was above 0.95 , except for those of $C$. choii and $S$. japonicus. Parameter $b$ for all species was within the expected range of 2.5-3.5 according to Froese (2006). Parameter $b$ of $C$. choii was 3.485 , which was the highest among the 12 species, and the other species showed small deviations from 3.0 for $b$. Parameter $a$ for $C$. choii, the only species in this study representing the family Cobitidae, was 0.0015 , which was the lowest observed, and $a$ of $A$. rhombeus was 0.0145 , which was the highest.

\section{Discussion}

Parameter $b$ for $C$. choii was 3.485 , which was high compared with that of other species, and such a high value of $b$ could be caused by various reasons. One possibility is the narrow size range (Froese 2006). However, in the presently reported study, the total length range of $C$. choii was $3.5-8.5 \mathrm{~cm}$, which was wide enough to cover juveniles through to fully grown adults. The second possibility was the small sample size, which contained a bias for large specimens. For example, large specimens could temporarily become heavier than usual because of the development of eggs or gonads during the spawning season or because large specimens could be in a much better nutritional condition than juveniles. The sample of $C$. choii in this study contained only 29 individuals, which is quite small, and could be the reason for the high value of $b$. The final possibility is that the fish changed their body shape as they grew. Several studies have reported positive allometric growth of Cobitis fish (Boron et al. 2008; Patimar et al. 2011). In particular, Cobitis keyvani Mousavi-Sabet, Yerli, Vatandoust, Özeren et Moradkhani, 2012 from the Sefid-rud River of Iran showed a $b$ value of 3.411 (Mousavi-Sabet et al. 2016), which is similar to our result. Nevertheless, more detailed investigations are needed to verify this result, and it seems reasonable to refer to our results as a case study from a specific fish population.

The LWR of $G$. naktongensis seemed to be reliable because the data used for the estimation satisfied the majority of the conditions proposed by Froese et al. (2011). The sample included approximately $100 \mathrm{spec}-$ imens, which was adequate, and the length range was wide enough to cover juveniles to adults. The coefficient of determination $\left(r^{2}\right)$ was higher than 0.950 , indicating that the outliers were sufficiently removed. Parameter $b$ was slightly higher than 3.0 , which is common considering the tendency of the majority of fishes to increase in thickness as they grow (Froese 2006).

Parameter $a$ is related to the body shape of fish (Froese 2006). In the presently reported study, the $a$ of $C$. choii was the lowest and that of $A$. rhombeus was the highest. Cobitis choii was the only species representing the family Cobitidae, which consists of loaches that have an elongated body shape. Acheilognathus rhombeus is a representative of the family Acheilognathidae and has a relatively short and deep body shape compared to the other fish examined.

In this study, the LWRs of C. choii and G. naktongensis were estimated, which are not currently available in FishBase (Froese and Pauly 2021). We expect that the results from this study will be useful as baseline information for evaluating the population status of these species in South Korea.

\section{Author contribution}

Conceptualization, JDY; methodology, SHB; software, SHB; validation, SHP, JHK, JHY, and JSM; formal analysis, JHK and DHK; investigation, SHP and JHK; resources, SHK, JHK and DHK; data curation, SHB and DHK; writing - original draft preparation, SHB and JDY; writing - review and editing, JHY; supervision, JDY; project administration, JHY and JSM; funding acquisition, JSM. All authors have read and accepted the final version of the manuscript.

\section{Acknowledgments}

This work was supported by a grant from the National Institute of Environment Research (NIER), funded by the Ministry of Environment (MOE) of the Republic of Korea (NIER-2021-04-02-002, NIER-SP2020-300).

\section{References}

Al-Zibdah M, Odat N (2007) Fishery status, growth, reproduction biology and feeding habit of two scombrid fish from the Gulf of Aqaba, Red Sea. Lebanese Science Journal 8(2): 3-20.

Boroń A, Jeleń I, Juchno D, Przybylski M, Borzuchowska E (2008) Age and growth of the karyologically identified spined loach Cobitis taenia (Teleostei, Cobitidae) from a diploid population. Folia Zoologica 57(1/2): 155 .

Brönmark C, Miner JG (1992) Predator-induced phenotypical change in body morphology in crucian carp. Science 258(5086): 1348-1350. https://doi.org/10.1126/science.258.5086.1348
Fricke R, Eschmeyer WN, Van der Laan R (2021) Eschmeyer's cata$\log$ of fishes: Genera, species, references. [Accessed 29 Nov 2021] http://researcharchive.calacademy.org/research/ichthyology/cata$\log$ /fishcatmain.asp

Froese R (2006) Cube law, condition factor and weight-length relationships: History, meta-analysis and recommendations. Journal of Applied Ichthyology 22(4): 241-253. https://doi.org/10.1111/j.14390426.2006.00805.x

Froese R, Pauly D (2021) FishBase. [Accessed 29 Nov 2021] http:// www.fishbase.org 
Froese R, Tsikliras AC, Stergiou KI (2011) Editorial note on weightlength relations of fishes. Acta Ichthyologica et Piscatoria 41(4): 261-263. https://doi.org/10.3750/AIP2011.41.4.01

Froese R, Thorson JT, Reyes RB Jr (2014) A Bayesian approach for estimating length-weight relationships in fishes. Journal of Applied Ichthyology 30(1): 78-85. https://doi.org/10.1111/jai.12299

Karna SK, Sahoo D, Panda S (2012) Length weight relationship (LWR), growth estimation and length at maturity of Etroplus suratensis in Chilika Lagoon, Orissa, India. International Journal of Environmental Sciences 2(3): 1257-1267. https://doi.org/10.6088/ijes.00202030012

Kim HS, Yang H, Hong YK (2014) Population ecology of endangered fish Gobiobotia naktongensis inhabiting the Gamcheon stream, Nakdonggang River (Pisces: Gobioninae). Korean Journal of Ichthyology 26(1): 1-10. https://doi.org/10.35399/ISK.31.1.1

Ko MH, Moon SJ, Lee SJ, Bang IC (2012) Community structure of fish and inhabiting status of endangered species, Cobitis choii and Gobiobotia naktongensis in the Ji stream, a tributary of the Geum River drainage system of Korea. Korean Journal of Ecology and Environment 45(4): 356-367. https://doi.org/10.11614/KSL.2012.45.4.356
LeCren ED (1951) The length-weight relationship and seasonal cycle in gonad weight and condition in the perch (Perca fluviatilis). Journal of Animal Ecology 20(2): 201-219. https://doi. org/10.2307/1540

Mousavi-Sabet H, Heidari A, Abbasi K, Vatandoust S (2016) Length-weight relationships of six species of the genera Cobitis and Sabanejewia (Cobitidae) in Iranian river systems. Journal of Applied Ichthyology 32(6): 1310-1312. https://doi.org/10.1111/ jai. 13142

NIBR (2018) [Endangered wildlife at a glance.] National Institute of Biological Resources, Ministry of Environment, Incheon, South Korea 220 pp. [In Korean]

Patimar R, Amouei M, Langroudi SMMA (2011) New data on the biology of Cobitis cf. satunini from the southern Caspian basin (northern Iran). Journal of Vertebrate Biology 60(4): 308-314. https://doi. org/10.25225/fozo.v60.i4.a7.2011

Ricker WE (1973) Linear regressions in fishery research. Journal of the Fisheries Research Board of Canada 30(3): 409-434. https://doi. org/10.1139/f73-072 